\title{
Nutritional Assessment of the Elderly: a Comparative study between residents of Geriatric Homes versus Community living Population, Tanta, Egypt
}

\section{Noha M. Elghazally, Shimaa M. Saied}

Public Health and Community Medicine Department,Tanta Faculty of Medicine, Tanta University, Egypt

\section{Abstract:}

Background: A higher incidence of malnutrition in the elderly is well distinguished. Malnutrition in geriatrics is a multidisciplinary concept, including physical, social and psychological elements. Methods: A comparative Cross-sectional study was performed to assess the nutritional status of elderly living in old age homes and those living in the community, in Tanta City. Subjects aged over 60 years were included in this study. Evaluation of nutritional status was done via anthropometric measurements and through data collected using the Mini Nutritional Assessment. A total of 185 subjects participated in this study. The study subjects were 56 residents of geriatric homes and 129 people who were residing in their houses. Results showed that the community residing elderly people had higher MNA scores compared to those living in geriatric homes ( $\mathrm{p}<0.001$ ). The MNA results among the old age home residents revealed that $17.9 \%$ of subjects were malnourished, and that $46.4 \%$ of them were at risk of malnutrition. While in free-living elderly the prevalence of malnutrition was $8.5 \%$, those at risk of malnutrition were $35.7 \%$. Conclusion: previous results showed the importance to screen and monitor elderly people and to share families in the proper nutritional care of the elderly.

Keywords: Elderly, Malnutrition, Anthropometric measurements, Mini Nutritional assessment

Introduction:The expansion in the elderly people is a worldwide trend reflecting the prolongation in life expectancy owing to the demographic transition in frequent nations. ${ }^{(1)}$ That is attributed to lower in mortality arising from the longer lifespan of people and enhancements in public services and clinical care leading to management of infectious diseases. ${ }^{(2)}$ The proportion of the aged is rising promptly around the world. The worldwide figure of the elderly is anticipated to grow from an approximate 524 million in 2010 to about 1500 million in 2050, with a major rise in the less developed countries. ${ }^{(3)}$

There is an expected rise in the number of elder persons aged 60 years or over more than twice in 2050 and to more than triple by the year 2100. Globally, an expected ascent from 962 million in 2017 to be about 2.1 billion by 2050, and 3.1 billion by 2100 . Around the world, the increase in individuals aged 60 or more are faster than among all younger age groups. ${ }^{(4)}$ Nutrition screening of elderly is extremely complicated; the shortcomings of previously existing screening instruments do not make the problem any simpler. ${ }^{(5)}$

The Mini nutritional assessment (MNA) tool is a non-invasive perfect practical, and validated instrument utilized for assessino malnutrition in the elderly.

*Corresponding author: E-mail: nohaelghazally1@ gmail.com 
malnutrition prior to marked changes happen in weight or serum proteins and can be utilized in a diversity of health-care settings as well as the community, when it was compared with a clinical evaluation by two nutrition expert physicians; the tool's accuracy was revealed to be $92 \%$ and raised to $98 \%$ when it was compared with a comprehensive nutritional assessment, including anthropometric measurements, dietetic evaluation, in addition to biochemical testing. ${ }^{(6)}$

Studies concerning the Egyptian aged population and their nutritional care are still scarce. Consequently, it was expected that this research would add helpful data about the magnitude of the problem and be useful for understanding malnutrition-related problems in the elderly. This study was conducted in Tanta City with the main objective of assessing and comparing the nutritional status of the elderly population who reside with their families in the community, and those residing in geriatric homes.

Methods:This is a comparative cross-sectional study conducted at Tanta City; which is the capital of the Egyptian governorate 'Gharbia'- the country's ninth largest populated area with about 5.3 million inhabitants in 2017. The study was conducted over a period of two months from $1^{\text {st }}$ April to $31^{\text {th }}$ May 2017 at 3 randomly selected governmental geriatric homes under the supervision of the ministry of social affairs which shelter elderly males and females. Each geriatric home consisted of three floors. The base was a reception and kitchen. The other two floors include rooms for elderly, each room has from four to five elderly inside. There total number was 69 persons;10 of them (14.49\%) were excluded and 56 persons of the residing elderlies- who met the inclusion criteria- agreed to participate in the study, with a response rate $(94.1 \%)$.

The elderly from the community were living in 3 randomly selected residential blocks in Tanta city. From houses of each block, old people, who met the inclusion criteria and agreed to participate in the study were chosen. In addition, as it was a period bound study, those aged subjects living with their families who were accessible during the limited time were incorporated.

Inclusion Criteria: Individuals aged 60 years and above willing to participate in the study and their medical conditions in addition to cognitive functions permit their participation. 
Exclusion Criteria: Aged people who were living alone, critically ill bedridden elderly patients, those receiving artificial enteral or parenteral nutrition, those with impaired cognitive functions, subjects with cancer, end-stage renal disease or terminal illness were excluded from the study.

The total number of instituted elderlies who met the inclusion criteria and agreed to participate was 56 persons, and the community living elders constituted 129 participants.

Data collection: The data were collected via the interview technique and anthropometric measurements. A semi-structured questionnaire was utilized to collect socio-demographic characteristics, the standard of living and physical health condition of participants. The screening tool mini nutritional assessment (MNA) ${ }^{(7)}$ was used.

Mini Nutritional Assessment (MNA) tool: MNA scale was utilized to assess the nutritional status of the elderly. It comprises questions and measurements gathered into four areas:

- Anthropometric measurements: Weight, height, and weight loss .

- General assessment: Six questions related to lifestyle, medications, and mobility

- Dietary evaluation: Eight questions linked to the number of meals, food and fluid intake and autonomy of feeding.

- Self-assessment: Self-perception of health and nutrition. The MNA score was calculated as the sum of the points assigned to the responses of the 18 items. Elderly participants were classified into the following three groups according to the obtained score :

- Above 23.5: Satisfactory nutritional status .

- 17 to $23.5-$ At the risk of malnutrition

- Below 17-Malnutrition

Anthropometric measurements: Height, weight, mid-upper arm circumference (MUAC), calf circumference (CC) and triceps skinfold thickness (TSF) of all subjects were measured by standard techniques. The following cut-off anthropometric markers were used to define undernutrition which are widely used values for assessing nutritional status. ${ }^{(8)}$ Anthropometric measures were also considered as normal values when above 10th percentile (P10-reference value) for age and gender.

- Calf circumference: $<31 \mathrm{~cm}$

- Mid-upper arm circumference: $<22 \mathrm{~cm}$

- Triceps skinfold thickness: male $<8$, female $<12 \mathrm{~mm}$

- Arm muscle area: male $<41$, female $<30 \mathrm{~cm}^{2}$

- Arm muscle circumference: male $<23.5$, female $<20 \mathrm{~cm}$

Body mass index (BMI) of all subjects were calculated:

Body mass index was calculated by dividing the measured weight in kilograms by the square of the body height in meters $\left(\mathrm{BMI} \mathrm{kg} / \mathrm{m}^{2}\right)$ and categorized into four weight classes; >20 (very low), $20-<24$ (low), $24-<29$ (desirable), and $\geq 29$ (high) (47). Additionally, BMI $<22 \mathrm{~kg} / \mathrm{m}^{2}$ considered as cut off for undernutrition ${ }^{(9)}$.

Data Management: The Statistical Program SPSS for Windows version 22.0 (IBM SPSS Statistics for Mac, released 2011; IBM Corp., Armonk, New York, USA; SPSS Inc., Chicago, Illinois, USA) was used for data entry and analysis. Quantitative data were presented by mean and standard deviation, while qualitative data were presented by frequency distribution. Chi- 
square test was used to compare more than one proportion. Student t-test was used to compare two means. The probability of less than 0.05 was used as a cut off point for all significant tests.

Ethical considerations: Approval from the concerned authorities was taken, together with an informed verbal consent was taken from all the subjects. The nature, reason, and objectives of the study were clarified to the chosen elderly and their relatives and family members also and confidentiality was guaranteed.The study was approved by Tanta Faculty of Medicine Research Ethics Committee (REC).

Results: Out of the total studied 185 elderly population, 56 subjects were inmates of old age homes and 129 subjects were residing at their houses with their families (community living). Their ages ranged between 60 and 100 years. Mean age of elderly in geriatric homes was (68.806 $\pm 6.87622)$ and was $(71.75 \pm 8.79)$ for the community living ones, with a statistically significant difference between them $(\mathrm{t}=2.27, \mathrm{p}=0.02 *)$. They were 76 males $(58.9 \%)$, and 53 females $(41.1 \%)$ living in their houses, and 36 males (64.3\%) and 20 females (35.7\%) residing in elderly homes with no statistical difference ( $\mathrm{p}=0.1)$. Regarding their marital status, 63 (48.8\%) of the community living elderly were married, while $25(44.6 \%)$ of elderly in nursing homes were widows, with a non-statistically significant difference $\left(\chi^{2}=19.4, \mathrm{p}=0.086\right)$. Among elderly living in nursing homes, 18 (32.1\%) had secondary education and 25 (44.6\%) were employees, and among elderly in their private homes, $55(42.6 \%)$ had secondary education and worked as unskilled manual workers with a non-statistically significant difference between them (Table 1).

The mean weight and height were $(82.3 \pm 16.58,164.22 \pm 10.73)$, respectively of those living in their houses, and was $(82.7843 \pm 17.47,160.69 \pm 10.9)$ among those living in nursing homes with a non-statistically significant difference $(\mathrm{p}=0.86, \mathrm{p}=0.051)$.

The mean BMI of elderly living in elderly homes was $31.938 \pm 6.603$ and was $30.69 \pm 6.5$ for elderly living in their private houses with no statistically significant difference $(t=1.192$, $\mathrm{p}=0.235$ ). The mean MNA scores were higher in the community living subjects compared to those in old age homes ( $\mathrm{p}<0.001)$. By screening, $19.6 \%$ of elderly in old age homes were malnourished vs $6.2 \%$ in their homes with a statistically significant difference $(\mathrm{p}=0.004)$. The malnutrition prevalence was $8.5 \%$ in the free-living elderly compared to $17.9 \%$ among geriatric home residents (by MNA) with a statistically significant difference $(\mathrm{p}=0.006)$ (Figure 1). 
The studied populations were divided into three age groups: $60-69,70-79$, and $\geq 80$ years. More than half of the elderly in their homes, and more than two-thirds of elderly in geriatric homes over eighty years old were malnourished, and at risk of malnutrition. No difference in the distribution of malnutrition among male and female elderly either in their homes or in old age homes (Table 2). Higher percentage of malnutrition was revealed among elderly who had chronic diseases (such as diabetes, heart disease, stroke, cancer, and chronic respiratory diseases) compared to those without chronic diseases $(9.8 \%$ vs $3.7 \%$ and $21.4 \%$ vs $7.1 \%)$ among community living, and of elderly homes residents, respectively. This difference was statistically significant $(\mathrm{P}=0.01)$ in the first group. Also, elderly persons who had teeth problems showed higher percentage of malnutrition (9.7\% and 24.2\%) among community-living elderly, and of elderly homes residents, respectively and the difference was statistically significant $(\mathrm{p}=0.04)$ (Table 3).

Total MNA scores positively correlated with BMI, there was a significant positive correlation among the elderly at geriatric homes $(r=0.688, \mathrm{p}<0.005)$ (Table 4).

Discussion: In the present study, the prevalence of malnutrition was $8.5 \%$ among the free-living elderly, and $17.9 \%$ in old age home residents (by MNA) (figure 1). The prevalence of malnutrition in free-living elderly is more than that found by Pai, $2011^{(1)}$ but less than in Mathew, 2016. ${ }^{(10)}$ In old age home residents, the number of people who were malnourished is nearly the same as that found by Singh et al. ${ }^{(11)}$. However, it is more than that found in a study conducted by Nazemi et al., in Iran among 263 residents of old age homes resulted that $10 \%$ were classified as malnourished. ${ }^{(12)}$

According to MNA, those at risk of malnutrition were $46.4 \%$ in old age home residents and $35.7 \%$ in free-living elderly subjects. However, $44.2 \%$ and $64.3 \%$ subjects in homes and in old age home, respectively were either malnourished or at risk of developing malnutrition, which was close to the findings of similar research conducted at old age homes in Kathmandu metropolitan city in Nepal, where malnutrition was found to be $15.5 \%$ and those at risk of malnutrition was $61 \%$. $^{(11)}$

In Brazil, Amorim et al. reported $66 \%$ of the evaluated elderly as malnourished or at risk of malnutrition ${ }^{(13)}$, while Gordon et al. stated that $30 \%$ of participants were malnourished, and $56 \%$ were at risk of malnutrition in the UK. ${ }^{(14)}$ A study conducted in Iran by Aliabadi et al., where $42.7 \%$ of participants were well nourished, $45.3 \%$ of them were at risk of malnutrition and 
$12.0 \%$ were malnourished. ${ }^{(15)}$ This variation may be attributed to the variation of cultural and social habits that affects the nutritional habits of elderly people in different communities.

An institution-based study revealed that the prevalence of malnutrition as $5-10 \%$ in freeliving elderly to be $30-85 \%$ in homebound, nursing home, and hospitalized elderly ${ }^{(16)}$. Many other researchers demonstrated that in different nursing homes the proportion of the elderly population suffering from malnutrition varied from 15 to 71 percent and about 40 to 60 percent of the subjects at risk of malnutrition. ${ }^{(17-20)}$ Many factors appear to influence the nutritional condition evidenced by aging. ${ }^{21,22)}$

The body composition changes with age. ${ }^{(23)}$ Loss of muscle mass begins in the middle of adulthood and continues through old age. A dietary nutrient deficit with lower energy expenditure is related to decreased weight and height in the elderly. ${ }^{(24,25)}$ Underweight and malnutrition are positively linked with the aging process, and in addition accompanied by biological, physiological, and mental changes, such as oral cavity troubles, diminished smell and taste sensations and diminished cognitive and functional capacity. ${ }^{(26)}$

The present study shows no association between sex and malnutrition, similar results were found by Singh et al. ${ }^{(11)}$ Saeidlou et al. ${ }^{(27)}$, Donini et al. ${ }^{(28)}$, and Boulos et al. ${ }^{(29)}$ found a significant association between nutritional status and female gender. No association was found with respect to marital status, past occupation, and educational status. Also, similar results were found by Singh et al. ${ }^{(11)}$ In the current study, a significant difference in MNA scores among freeliving elderly and those in old age homes (Table 2). Similar results were found by Pai, in Mangalore city where 108 residents of old age homes and 102 people who were living in their houses, higher MNA scores ( $\mathrm{p}<0.001$ ) compared to those living in old age homes. ${ }^{(1)}$

In this study, the prevalence of malnutrition was higher among elderly persons who had chronic medical conditions vs. those without chronic diseases (Table 4). This is in agreement with Guigoz et al. who found that malnutrition in community-living elderly persons was related to chronic medical conditions. ${ }^{(30)}$ These findings could be due to the predominance of proteinenergy malnutrition that increases with age and the number of co-morbidities. ${ }^{(31)}$

Malnutrition was higher among elderly persons who had teeth problems (Table 4). In Italy, a survey among community-dwelling elderly (aged 70-75 years) showed a close relationship between dental health status and food intake. It was identified that the utilization of dentures can help to enhance both nutrient intake of the aged, and the quality of their life. ${ }^{(32)}$ People with a 
fewer number of teeth less than the optimal number, or without any dentures may face problems resulting from avoidance of certain foods. ${ }^{(33)}$ Elderly lacking dentures were found to prevent eating, had problems in chewing and majority of them changed their food composition and way of cooking to facilitate chewing. ${ }^{\text {(34) }}$

The MNA score showed a significant correlation with BMI only in nursing home residents (table 5). The same results were found by Ghimire et al., who said that BMI was significantly correlated with the total MNA score. ${ }^{(35)}$ Thomas et al. had found a high correlation of MNA score only with BMI. ${ }^{(36)}$ In Turkey, a study on 1564 elderly volunteers showed a decrease in MNA score with the increase in age. ${ }^{(37)}$

Conclusion: Prevalence of malnutrition (by using MNA) is significantly higher in old ages who resident at elderly homes compared to community living elderly. Mini Nutritional Assessment tool seems to be a reliable and applicable method to assess the nutritional status of elderly people, and there should be more attention for those who living in old age homes to manage their problems. It is recommended to use MNA as a screening tool to find older populations who are at risk and to take rapid intervention strategies. Paying attention to the nutritional needs of the elderly population can be helpful to improve the health and quality of life of the elderly.

Conflict of interests: We confirm that there are no known conflicts of interest associated with this publication.

Funding: There has been no financial support for this work that could have influenced its outcome.

\section{References:}

1. Pai, M. K.: Comparative study of nutritional status of elderly population living in the home for aged vs those living in the community.' Biomedical Research. 2011; 22 (1):120-126.

2. Mishra US, Irudaya Ragan S, and Sarma PS.: India's Elderly: Burden Or Challenge? New Delhi: Sage Publications and London: Thousand Oaks, 1999.

3. World Health Organization. National Institute on Aging, National Institutes of Health, United States. Global Health and Ageing.2011. Available from, http://www.who.int/ageing/publications/global_health.pdf. Accessed 11 June 2017

4. United Nations, Department of Economic and Social Affairs, Population Division. World $\begin{array}{llll}\text { Population Ageing } & 2015 . & \text { Available }\end{array}$ 
http://www.un.org/en/development/desa/population/publications/pdf/ageing/WPA2015_High lights.pdf. Last accessed 15-3-2018.

5. Schneider SM, Hebuterne X.: Use of nutritional scores to predict clinical outcomes in chronic diseases. Nutr. Rev. 2000; 58: 31-38.

6. Vellas B, Villars H, Abellan G, Soto ME, Rolland Y,Guigoz Y: Overview of the MNA - Its history and challenges. J Nutr Health Aging, 2006; 10:456-65.

7. Guigoz Y: The Mini-Nutritional Assessment (MNA) review of the literature: what does it tell us?. J Nutr Health Aging. 2006; 10:466-87.

8. Kuczmarski MF, Kuczmarski RJ, Najjar M.: Descriptive anthropometric reference data for older Americans. J Am Diet Assoc. 2000; 100:59-66.

9. Barendregt K SP, Allison SP, Kondrup J.: Diagnosis of malnutrition-screening and assessment. In: ESPEN: Basics in Clinical Nutrition Third ed. Editor-in-Chief Lubos Sobotka. Publ. House Galen Prague Czech Republic. 2004:11-20.

10. Mathew AC, Das D, Sampath S, Vijayakumar M, Ramakrishnan N, Ravishankar SL.: Prevalence and correlates of malnutrition among elderly in an urban area in Coimbatore. Indian J Public Health. 2016; 60 (2):112-7.

11. Singh DR, Shrestha S: Nutritional status of senior citizens living in old age homes of Kathmandu metropolitan municipality. Int J Community Med Public Health. 2016 Jul; 3 (7):1707-1715.

12. Nazemi L, Skoog I, Karlsson I, Hosseini S, Mohammadi MR, Hosseini M, et al.: Malnutrition, prevalence and relation to some risk factors among elderly residents of nursing homes in Tehran, Iran. Iran J Public Health.2015; 44:218-27.

13. Amorim Sena Pereira ML, de Almeida MP, Cunha De Oliveira C, Carneiro Roriz AK, Teresópolis Reis Amaral M, Lima Mello A et al.: Nutritional status of institutionalized elderly Brazilians: a study with the mini nutritional assessment. Nutr Hosp.2014; 31:11981204.

14. Gordon AL, Franklin M, Bradshaw L, Logan P, Elliott R , Gladman JR.: Health status of UK care home residents: a cohort study. Age Ageing.2014; 43:97-103.

15. Aliabadi M, Kimiagar M , Ghayour MM.: Prevalence of malnutrition in free living elderly people in Iran: a cross-sectional study. Asia Pacific J Clinic Nutri.2008; 17 (2):285-9. 
16. Guigoz Y, Vellas BJ.: Malnutrition in elderly: The Mini Nutritional Assessment.1997; 54 (50):345.

17. Lauque S, Arnaud-Battandier F, Mansourian R, Guigoz Y, Paintin M, Nourhashemi F.: Protein-energy oral supplementation in malnourished nursing-home residents. A controlled trial. Age Ageing.2000; 29: 51-6.

18. Gerber V, Krieg M, Cornuz J, Guigoz Y, Burckhardt P.: Nutritional status using the Mini Nutritional Assessment questionnaire and its relationship with bone quality in a population of institutionalized elderly women. J Nutr Health Aging,2003; 7: 140- 5.

19. Van Nes MC, Herrmann FR, Gold G, Michel JP, Rizzoli R.: Does the mini nutritional assessment predict hospitalization outcomes in older people? Age Ageing,2001; 30: 221- 6 .

20. Christensson L, Unosson M.: Evaluation of nutritional assessment techniques in elderly people newly admitted to municipal care. Eur J Clin Nutr, 2002; 56: 810-8.

21. Rejnefelt I, Andersson P, Renvert S.: Oral health status in individuals with dementia living in special facilities. Int J Dent Hyg.2006; 4:67 - 71.

22. Hopcraft MS, Morgan M, Satur JG, Wright FA.: Edentulism and dental caries in victorian nursing homes. Gerodontology. 2012; 29:512-9.

23. Kehayias JJ: Aging and Body Composition. In: Nutrition and Aging. Nestle Nutrition Workshop Series Clinical and Performance Programme. 2002; (6):63-78.

24. Elia M.: Obesity in the elderly. Obes Rest. 2001; 9: 244-48.

25. Santos JL, Albabla C, Lera L, Garcia C, Arryo P, Perez Bravo F: Anthropometric measurements in the elderly population of Santiago Chile. Nutrition.2004; 20: 45_48.

26. Faraes D, Barbosa AR, Borgatto AF, Coquetro RS and Fernandess MH.: Factors associated with nutritional status of the elderly in two regions of Brazil. Rev Assoc Med Bras. 2012; 58 (4):434-41.

27. Saeidlou SN, Merdol TK, Mikaili P, Bektas Y.: Assessment of the nutritional status and affecting factors of elderly people living at six nursing home in Urmia, Iran. Part I. Int J Acad Res. 2011; 3:1.

28. Donini LM, Scardella P, Piombo L, Neri B, Asprino R, Proietti AR: Malnutrition in elderly: Social and economic determinants. J Nutr Health Aging. 2013; 17:9-15. 
29. Boulos C, Salameh P, Barberger-Gateau P: The AMEL study, a cross sectional populationbased survey on aging and malnutrition in 1200 elderly Lebanese living in rural settings: Protocol and sample characteristics. BMC Public Health. 2013; 12 (13):573.

30. Guigoz Y, Lauque S , Vellas BJ.: Identifying the elderly at risk for malnutrition. The Mini Nutritional Assessment. Clin Geriatr Med. 2002; 18 (4):737-57.

31. Agarwal E, Miller M, Yaxley A, Isenring E.: Malnutrition in the elderly: a narrative review. 2013; 4 (76):296-302.

32. Appollonio I, Carabellese C, Frattola A, Trabucchi M.: Influence of dental status on dietary intake and survival in community-dwelling elderly subjects. Age Ageing.1997; 26: 445- 55.

33. Roessler DM.: Complete denture success for patients and dentists. Int Dent J.2003;53: 340-5.

34. Sheiham A, Steele JG, Marcenes W, Tsakos G, Finch S, Walls AW.: Prevalence of impacts of dental and oral disorders and their effects on eating among older people; a national survey in Great Britain. Community Dent Oral Epidemiol.2001; 29: 195- 203.

35. Ghimire S, Baral BK, Callahan K: Nutritional assessment of community-dwelling older adults in rural Nepal.2017; 12 (2).

36. Thomas DR, Zdrowski CD, Wilson M, Conright KC, Lewis C, Tariq S et al.: Malnutrition in subacute care. American Journal of Clinical Nutrition. 2002; 75 (2): 308-313.

37. Kucukerdonmez O, Koksal E, Rakicioglu N, Pekcan G: Assessment and evaluation of the nutritional status of the elderly using 2 different instruments. Saudi Medical Journal.2005; 26 (10): 1611-16. 
Table (1): Sociodemographic features of the studied sample

\begin{tabular}{|c|c|c|c|c|}
\hline Feature & & $\begin{array}{c}\text { Community living } \\
(\mathrm{n}=129)\end{array}$ & $\begin{array}{c}\text { Elderly Homes } \\
(\mathbf{n}=56)\end{array}$ & $\begin{array}{c}\text { Test of } \\
\text { significance }\end{array}$ \\
\hline \multirow[t]{2}{*}{ Sex } & - Male & $76(58.9 \%)$ & $36(64.3 \%)$ & \multirow{2}{*}{$\begin{array}{c}\chi^{2}=0.47 \\
\mathrm{p}=0.1\end{array}$} \\
\hline & - Female & $53(41.1 \%)$ & $20(35.7 \%)$ & \\
\hline \multicolumn{4}{|c|}{$\begin{array}{l}68.81+6.88 \\
71.75+8.79\end{array}$} & $\begin{array}{l}\mathrm{t}=2.227 \\
\mathrm{p}=0.02^{*}\end{array}$ \\
\hline \multirow{4}{*}{$\begin{array}{l}\text { Marital } \\
\text { Status }\end{array}$} & - $\quad$ Married & $63(48.8 \%)$ & $14(25.0 \%)$ & \multirow{4}{*}{$\begin{array}{c}\chi^{2}=19.4 \\
\mathrm{p}=0.006^{*}\end{array}$} \\
\hline & - Single & $4(3.1 \%)$ & $9(16.1 \%)$ & \\
\hline & - Widow & $56(43.4 \%)$ & $25(44.6 \%)$ & \\
\hline & - Divorced & $6(4.7 \%)$ & $8(14.3 \%)$ & \\
\hline \multirow{4}{*}{$\begin{array}{l}\text { Educational } \\
\text { level }\end{array}$} & - Illiterate & $18(14 \%)$ & $8(14.3 \%)$ & \multirow{4}{*}{$\begin{array}{c}\chi^{2}=2.2 \\
\mathrm{p}=0.449\end{array}$} \\
\hline & - Primary & $35(27.1 \%)$ & $17(30.4 \%)$ & \\
\hline & - Secondary & $55(42.6 \%)$ & $18(32.1 \%)$ & \\
\hline & - High & $21(16.3 \%)$ & $13(23.2 \%)$ & \\
\hline \multirow[t]{5}{*}{ Occupation } & - Not working & $7(5.4 \%)$ & $1(1.8 \%)$ & \multirow{5}{*}{$\begin{array}{l}\chi^{2}=2.5 \\
\mathrm{p}=0.2\end{array}$} \\
\hline & $\begin{array}{l}\text { Unskilled } \\
\text { manual } \\
\text { worker }\end{array}$ & $55(42.6 \%)$ & $23(41.1 \%)$ & \\
\hline & $\begin{array}{l}\text { Skilled } \\
\text { manual } \\
\text { worker }\end{array}$ & $16(12.4 \%)$ & $7(12.5 \%)$ & \\
\hline & $\begin{array}{l}\text { Retired } \\
\text { Employees }\end{array}$ & $49(38.0 \%)$ & $25(44.6 \%)$ & \\
\hline & $\begin{array}{ll}\text { - } & \text { Retired } \\
& \text { Professional }\end{array}$ & $2(1.6 \%)$ & $0(0.0 \%)$ & \\
\hline
\end{tabular}

*statistically significant 


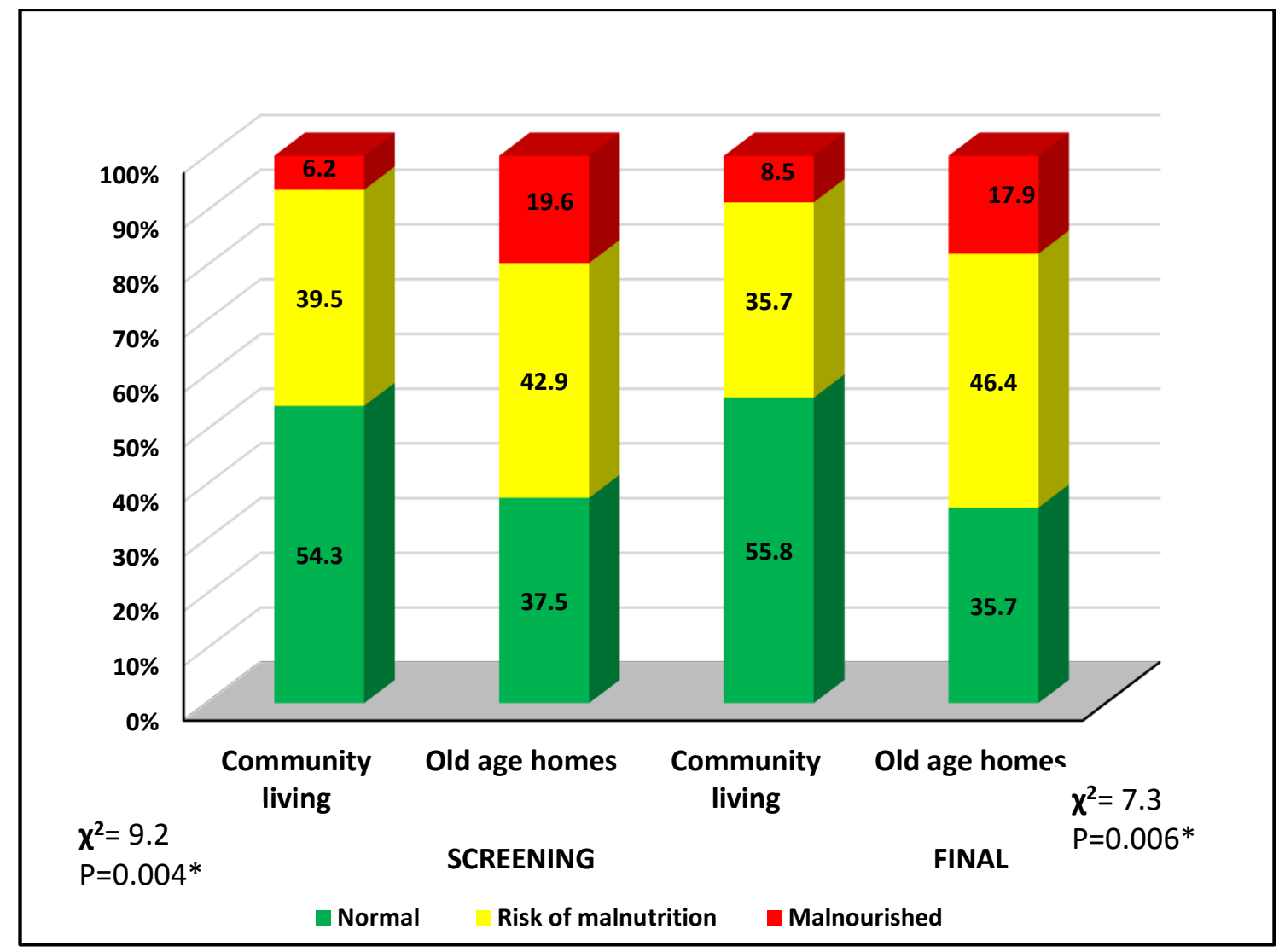

*statistically significant

Figure (1): Assessment of Malnutrition according to Mini Nutritional Assessment 
Table (2): Distribution of malnutrition (based on MNA questionnaire) according to sociodemographic factors

\begin{tabular}{|c|c|c|c|c|}
\hline \multirow[t]{2}{*}{ MNA score } & \multicolumn{3}{|c|}{ Age groups } & \multirow{3}{*}{$\begin{array}{c}\text { Test of } \\
\text { significance }\end{array}$} \\
\hline & 60-69years & 70-79 years & $\geq 80$ years & \\
\hline Community living & No. $(\%)$ & No. (\%) & No. $(\%)$ & \\
\hline - Malnourished & $3(3.9 \%)$ & $5(11.9 \%)$ & $3(27.3 \%)$ & \multirow[t]{3}{*}{$\mathrm{P}=0.052$} \\
\hline 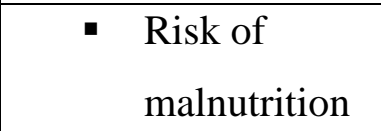 & $29(38.2 \%)$ & $14(33.3 \%)$ & $3(27.3 \%)$ & \\
\hline - Normal & $44(57.9 \%)$ & $23(54.8 \%)$ & $\begin{array}{ll}5 & (45.5 \%)\end{array}$ & \\
\hline Old age homes & No. (\%) & No. (\%) & No. (\%) & \multirow{4}{*}{$\mathrm{P}=0.348$} \\
\hline - Malnourished & $3(12.5 \%)$ & $5(27.8 \%)$ & $2(14.3 \%)$ & \\
\hline 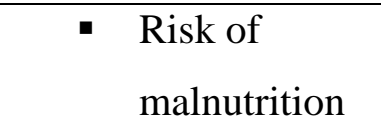 & $12(50 \%)$ & $6(33.3 \%)$ & $8(57.1 \%)$ & \\
\hline - Normal & $9(37.5 \%)$ & $7(38.9 \%)$ & $4(28.6 \%)$ & \\
\hline \multirow[t]{2}{*}{ - MNA Score } & \multicolumn{3}{|c|}{ Sex } & Test of \\
\hline & Male & \multicolumn{2}{|c|}{ Female } & \multirow{5}{*}{$\begin{array}{l}\chi^{2}=3.7 \\
P=0.34\end{array}$} \\
\hline Community living & No. (\%) & \multicolumn{2}{|c|}{ No. (\%) } & \\
\hline - Malnourished & $4(5.3 \%)$ & \multicolumn{2}{|c|}{$7(13.2 \%)$} & \\
\hline $\begin{array}{ll} & \text { Risk of } \\
\text { malnutrition }\end{array}$ & $31(40.8 \%)$ & \multicolumn{2}{|c|}{$15(28.3 \%)$} & \\
\hline - Normal & $41(53.9 \%)$ & \multicolumn{2}{|c|}{$31(58.5 \%)$} & \\
\hline Old age homes & No. $(\%)$ & \multicolumn{2}{|c|}{ No. (\%) } & \multirow{4}{*}{$\begin{array}{l}\chi^{2}=0.316 \\
p=0.359\end{array}$} \\
\hline - $\quad$ Malnourished & $7(19.4 \%)$ & \multicolumn{2}{|c|}{$3(15 \%)$} & \\
\hline $\begin{array}{l}\text { Risk of } \\
\text { malnutrition }\end{array}$ & $17(47.2 \%)$ & \multicolumn{2}{|c|}{$9(45 \%)$} & \\
\hline - Normal & $12(33.3 \%)$ & \multicolumn{2}{|c|}{$8(40.0 \%)$} & \\
\hline
\end{tabular}

*statistically significant

Table (3): Relation between MNA scores and presence of diseases among the studied sample 
Elghazally and Saied: Nutritional Assessment of the Elderly

\begin{tabular}{|c|c|c|c|}
\hline \multirow[t]{2}{*}{ MNA score } & \multicolumn{2}{|c|}{ Chronic diseases" } & \multirow[t]{3}{*}{ Test of significance } \\
\hline & No & yes & \\
\hline Community living & $\mathrm{n}(\%)$ & $\mathrm{n}(\%)$ & \\
\hline - Malnourished & $1(3.7 \%)$ & $10(9.8 \%)$ & \multirow{4}{*}{$\begin{array}{l}\chi^{2}=6.69 \\
\mathrm{p}=0.01 *\end{array}$} \\
\hline $\begin{array}{l}\text { - } \text { Risk of } \\
\text { malnutrition }\end{array}$ & $5(18.5 \%)$ & $41(40.2 \%)$ & \\
\hline - Normal & $21(77.8 \%)$ & $51(50 \%)$ & \\
\hline Old age homes & n (\%) & $\mathrm{n}(\%)$ & \\
\hline - Malnourished & $1(7.1 \%)$ & $9(21.4 \%)$ & \multirow{3}{*}{$\begin{array}{c}\chi^{2}=2.7 \\
\mathrm{P}=0.508\end{array}$} \\
\hline $\begin{array}{ll} & \text { Risk of } \\
\text { malnutrition }\end{array}$ & $9(64.3 \%)$ & $17(40.5 \%)$ & \\
\hline \multirow[t]{2}{*}{ - Normal } & $4(28.6 \%)$ & $16(38.1 \%)$ & \\
\hline & \multicolumn{2}{|c|}{ Teeth problems } & \multirow{5}{*}{$\begin{array}{l}\chi^{2}=0.874 \\
\mathrm{P}=0.223\end{array}$} \\
\hline Community living & No & Yes & \\
\hline - Malnourished & $5(7.5 \%)$ & $6(9.7 \%)$ & \\
\hline $\begin{array}{l}\text { - } \text { Risk of } \\
\text { malnutrition }\end{array}$ & $22(32.8 \%)$ & $24(38.7 \%)$ & \\
\hline - $\quad$ Normal & $40(59.7 \%)$ & $32(51.6 \%)$ & \\
\hline \multicolumn{3}{|l|}{ Old age homes } & \multirow{4}{*}{$\begin{array}{c}\chi^{2}=3.5 \\
\mathrm{P}=0.04 *\end{array}$} \\
\hline - Malnourished & $2(8.7 \%)$ & $8(24.2 \%)$ & \\
\hline $\begin{array}{l}\text { Risk of } \\
\text { malnutrition }\end{array}$ & $10(43.5 \%)$ & $16(48.5 \%)$ & \\
\hline - Normal & $11(47.8 \%)$ & $9(27.3 \%)$ & \\
\hline
\end{tabular}

\# Chronic diseases: Diabetes, heart disease, stroke, cancer, chronic respiratory diseases *statistically significant 
Elghazally and Saied: Nutritional Assessment of the Elderly

Table (4): Correlation coefficients for MNA score according to residence:

\begin{tabular}{|c|c|c|}
\hline \multirow{2}{*}{ Measurement } & \multicolumn{2}{|c|}{ Score of MNA } \\
\cline { 2 - 3 } & $\begin{array}{c}\text { Community living } \\
\mathrm{r}(\mathrm{p})\end{array}$ & $\begin{array}{c}\text { Old age homes } \\
\mathrm{r}(\mathrm{p})\end{array}$ \\
\hline Age (years) & $-0.12(0.175)$ & $-0.055(0.688)$ \\
\hline BMI (kg/m2) & $0.130(0.142)$ & $0.373\left(0.005^{*}\right)$ \\
\hline
\end{tabular}

*statistically significant

(MNA): Mini Nutritional Assessment 
Elghazally and Saied: Nutritional Assessment of the Elderly

\section{الملخص العربي}

التقييم الغذائي لكبار السن: مقارنة الوضع التظذوي بين نزلاء دور المسنين و المقيمين بمنازلهم في مدينة طنطا -بجمورية مصر العربية

نهي محمد الغز الي ـ شيماء محمد سعيد

الظلفيه العلميه: يشكل سوء التخذية مشكلة متز ايدة بين كبار السن. ويعتبر سوء التغذية في المسنين مفهومًا متعدد الأبعاد ،حيث يشمل عو امل صحية واجتماعية ونفسية. الأهداف: تقييم الحالة التغذوية لكبار السن الذين يقيمون في دور المسنين والذين يعيشون مع عائلاتهم في مدينة طنطا.طريقة البحث: تضمنت الدراسة اجر اء مقابلة مع المسنين الذين تزيد أعمار هم عن ستين عامًا و تقييم حالتهم التغذوية من خلال إجر اء القياسات المختلفة وأيضا من خلال جمع البيانات باستخدام استمارة التقييم الغذائي و قد شارك مائة وخمس وثمانون مسنًا في هذه الدراسة; منهم ستة و خمسون نزيل في دور المسنين ومائة و تسعة عشرون. مسن يقيمون في منازلهم.النتائج: أظهرت النتائج أن حو الي 18\% من قاطني دور المسنين كانو يعانون من سوء التغذية و حوالي 46 \% منهم في خطر من الإصابة بسوء التغذية وقلت النسبة عن ذلك بين المسنين الذين يعيشون مع عائلاتهم إلى 8.5 مصابين بسوء تغذية وحو الي 36\% على خطر الاصابة بسوء التخذية. الخلاصة: أظهرت هذه النتائج أهمية الفحص المبكر و المتابعة الدائمة لكبار السن وضرورة مشاركة العائلات في الرعاية الغذائية المناسبة لكبار السن وتقديم الدعم المستمر الدره 